\title{
Front Matter: Volume 9311
}

, "Front Matter: Volume 9311," Proc. SPIE 9311, Molecular-Guided Surgery: Molecules, Devices, and Applications, 931101 (9 March 2015); doi:

10.1117/12.2183946

SPIE. Event: SPIE BiOS, 2015, San Francisco, California, United States 


\title{
PROGRESS IN BIOMEDICAL OPTICS AND IMAGING \\ Vol. 16 No. 9
}

\section{Molecular-Guided Surgery: \\ Molecules, Devices, and Applications}

\author{
Brian W. Pogue \\ Sylvain Gioux \\ Editors
}

7-8 February 2015

San Francisco, California, United States

Sponsored by

SPIE

Cosponsored by

Intuitive Surgical, Inc. (United States)

LI-COR, Inc. (United States)

Novadaq Technologies Inc.

Published by

SPIE 
The papers included in this volume were part of the technical conference cited on the cover and title page. Papers were selected and subject to review by the editors and conference program committee. Some conference presentations may not be available for publication. The papers published in these proceedings reflect the work and thoughts of the authors and are published herein as submitted. The publisher is not responsible for the validity of the information or for any outcomes resulting from reliance thereon.

Please use the following format to cite material from this book:

Author(s), "Title of Paper," in Molecular-Guided Surgery: Molecules, Devices, and Applications, edited by Brian W. Pogue, Sylvain Gioux, Proceedings of SPIE Vol. 9311 (SPIE, Bellingham, WA, 2015) Article CID Number.

ISSN: 1605-7422

ISBN: 9781628414011

Published by

SPIE

P.O. Box 10, Bellingham, Washington 98227-0010 USA

Telephone +1 3606763290 (Pacific Time) · Fax +1 3606471445

SPIE.org

Copyright (C) 2015, Society of Photo-Optical Instrumentation Engineers.

Copying of material in this book for internal or personal use, or for the internal or personal use of specific clients, beyond the fair use provisions granted by the U.S. Copyright Law is authorized by SPIE subject to payment of copying fees. The Transactional Reporting Service base fee for this volume is $\$ 18.00$ per article (or portion thereof), which should be paid directly to the Copyright Clearance Center (CCC), 222 Rosewood Drive, Danvers, MA 01923. Payment may also be made electronically through CCC Online at copyright.com. Other copying for republication, resale, advertising or promotion, or any form of systematic or multiple reproduction of any material in this book is prohibited except with permission in writing from the publisher. The CCC fee code is $1605-7422 / 15 / \$ 18.00$.

Printed in the United States of America.

Publication of record for individual papers is online in the SPIE Digital Library.



SPIEDigitalLibrary.org

Paper Numbering: Proceedings of SPIE follow an e-First publication model, with papers published first online and then in print. Papers are published as they are submitted and meet publication criteria. A unique citation identifier (CID) number is assigned to each article at the time of the first publication. Utilization of CIDs allows articles to be fully citable as soon as they are published online, and connects the same identifier to all online, print, and electronic versions of the publication. SPIE uses a six-digit CID article numbering system in which:

- The first four digits correspond to the SPIE volume number.

- The last two digits indicate publication order within the volume using a Base 36 numbering

system employing both numerals and letters. These two-number sets start with 00, 01, 02, 03, 04, $05,06,07,08,09,0 A, 0 B \ldots$. OZ, followed by 10-1Z, 20-2Z, etc.

The CID Number appears on each page of the manuscript. The complete citation is used on the first page, and an abbreviated version on subsequent pages. 


\title{
Contents
}

\author{
$\checkmark \quad$ Authors \\ vii Conference Committee \\ ix Introduction
}

MOLECULAR-GUIDED SURGERY INTRODUCTION

931102 Molecular-guided surgery [9311-100]

ENDOGENOUS MOLECULAR CONTRAST

931106 Multispectral reflectance enhancement for breast cancer visualization in the operating room [931 1-4]

\section{ADVANCED MOLECULAR IMAGING METHODS}

9311 OC Quantitative fluorescence imaging enabled by spatial frequency domain optical-property mapping in the sub-diffusive regime for surgical guidance [9311-10]

9311 OD Tumor implantation model for rapid testing of lymphatic dye uptake from paw to node in small animals [9311-11]

\section{CLINICAL FLUORESCENCE IMAGING SYSTEMS}

93110 Augmented microscopy with near-infrared fluorescence detection [9311-16]

9311 0J The combination design for open and endoscopic surgery using fluorescence molecular imaging technology [9311-17]

MOLECULAR CONTRAST AGENTS

9311 OL Clinical trials in near infrared fluorescence imaging with IRDye 800CW (Invited Paper) [9311-19]

931100 Improved tumor identification using dual tracer molecular imaging in fluorescence guided brain surgery [9311-22] 
9311 OR A miniaturized imaging system for optical guided surgery of head and neck cancer [9311-25]

9311 OS Ex-vivo tissue classification of cell surface receptor concentrations using kinetic modeling [931 1-26]

9311 OT Small animal imaging plafform for quantitative assessment of short-wave infrared-emitting contrast agents [9311-27]

\section{CLINICAL APPLICATIONS}

9311 OU Image-guided surgery using near-infrared fluorescent light: from bench to bedside (Invited Paper) [931 1-28]

$93110 \mathrm{~V}$ Sentinel lymph node detection in breast cancer patients using surgical navigation system based on fluorescence molecular imaging technology (Invited Paper) [931 1-29]

$93110 \mathrm{X}$ Intraoperative imaging of tumors with indo-cyanine green fluorescence with an endoscope [9311-31]

\section{POSTER SESSION}

$93110 Z$ A miniature wearable optical imaging system for guiding surgeries [9311-33]

931112 Advancing molecular-guided surgery through probe development and testing in a moderate cost evaluation pipeline [9311-36]

931113 Method for accurate quantitation of background tissue optical properties in the presence of emission from a strong fluorescence marker [931 1-37]

931114 Radiometric calibration to consider in quantitative clinical fluorescence imaging measurements [9311-43] 


\section{Authors}

Numbers in the index correspond to the last two digits of the six-digit citation identifier (CID) article numbering system used in Proceedings of SPIE. The first four digits reflect the volume number. Base 36 numbering is employed for the last two digits and indicates the order of articles within the volume. Numbers start with 00, 01, 02, 03, 04, 05, 06, 07, 08, 09, OA, OB...0Z, followed by 10-1Z, 20-2Z, etc.

An, Yu, OJ

Anton, Rein, $\mathrm{Ol}$

Atallah, Ihab, OR

Barth, Richard J., OD

Boogerd, Leonora S. F., OU

Bravo, Jaime, 13

Brey, Eric M., 00

Byrne, Richard W., 00

Chi, Chongwei, OJ, OV

Chong, Sang Hoon, OX

Coll, Jean-LUC, OR

Conde, Olga M., 06

Davis, Scott C., 13

Dorval, Paul, OR

Draney, Daniel R., OL, 12

DSouza, Alisha V., OD

Elliott, Jonathan T., OC, OD

Feldwisch, Joachim, 12

Fernandez-Barreras, Gaspar, 06

Ganapathy, Vidya, OT

Gayet, Pascal, OR

Gioux, Sylvain, 02

Gunn, Jason R., OD, 12

Handgraaf, Henricus J. M., OU

Henry, Maxime, OR

Higgins, Laura M., OT

Hoopes, Jack, 12

$\mathrm{Hu}$, Philip, OT

Hull, Sally M., 12

Hurbin, Amandine, OR

Jiang, Shixin, OJ

Josserand, Véronique, OR

Kanick, Stephen Chad, 13

Khan, Altaz, OS

Kou, Deqiang, OV

Krishnaswamy, Venkataramanan, 06

Laughney, Ashley M., 06

Leblond, Frederic, OC

Lemole, G. Michael, 0

Litorja, M., 14

Liv, Jonathan T., OS

Liu, Yang, $\mathrm{OZ}$

López-Higuera, José M., 06

Mao, Yamin, OJ, OV

Martirosyan, Nikolay, 0

Mela, Christopher A., OZ

Milet, Clément, OR

Mingozzi, Marco, OT

Moghe, Prabhas V., OT
Moscatelli, Frank A., OX

Parthasarathy, Ashwin B., OX

Patterson, Carrie L., $\mathrm{OZ}$

Paulsen, Keith D., 06, 12, 13

Pierce, Mark C., OT

Pogue, Brian W., 02, 06, 0D, 12

Qiu, Jingdan, OV

Real, Eusebio, 06

Reyt, Emile, OR

Righini, Christian, OR

Riman, Richard E., OT

Rizo, Philippe, OR

Roberts, David W., OC

Roberts, David W., 12, 13

Romanowski, Marek, Ol

Roth, Charles M., OT

Samkoe, Kimberley S., OD, 12

Sibai, Mira, OC

Singhal, Sunil, OX

Sinha, Lagnojita, os

Skoch, Jesse, 01

Straus, David, 00

Strong, Theresa $\vee ., 12$

Tian, Jie, OJ, OV

Tichaver, Kenneth M., OD, 0O, OS

Torres, Veronica, 00

Urbas, A., 14

Vahrmeijer, Alexander L., OU

van de Velde, Cornelis J. H., OU

Veilleux, Israel, OC

Wang, Jiandong, OV

Wang, Yu, OS

Watson, Jeffrey R., Ol

Wilson, Brian C., OC

$\mathrm{Xu}$, Xiaochun, $0 \mathrm{O}$

Yang, Cynthia, OS

Yang, Xin, OJ, OV

Ye, Jinzuo, OJ, OV

Yodh, Arjun G., OX

Zevon, Margot, OT

Zong, Y., 14 
Proc. of SPIE Vol. $9311931101-6$

Downloaded From: https://www.spiedigitallibrary.org/conference-proceedings-of-spie on 25 Apr 2023 Terms of Use: https://www.spiedigitallibrary.org/terms-of-use 


\title{
Conference Committee
}

\author{
Symposium Chairs
}

James G. Fujimoto, Massachusetts Institute of Technology

(United States)

R. Rox Anderson, Wellman Center for Photomedicine, Massachusetts General Hospital (United States) and Harvard School of Medicine (United States)

Program Track Chair

Brian Jet-Fei Wong, Beckman Laser Institute and Medical Clinic (United States)

\section{Conference Chairs}

Brian W. Pogue, Thayer School of Engineering at Dartmouth (United States)

Sylvain Gioux, Beth Israel Deaconess Medical Center (United States)

\section{Conference Program Committee}

Hak Soo Choi, Beth Israel Deaconess Medical Center (United States)

David J. Cuccia, Modulated Imaging, Inc. (United States)

Daniel R. Draney, LI-COR Biosciences (United States)

Hisataka Kobayashi, National Cancer Institute (United States)

Vasilis Ntziachristos, Helmholtz Zentrum München GmbH (Germany)

Keith D. Paulsen, Thayer School of Engineering at Dartmouth (United States)

Jonathan M. Sorger, Intuitive Surgical, Inc. (United States)

Tomasz S. Tkaczyk, Rice University (United States)

Alex Vahrmeijer, Leiden University Medical Center (Netherlands)

Thomas D. Wang M.D., University of Michigan (United States)

Brian C. Wilson, Ontario Cancer Institute (Canada)

Siavash Yazdanfar, GE Global Research (United States)

Session Chairs

1 Endogenous Molecular Contrast

Stephen Chad Kanick, Thayer School of Engineering at Dartmouth (United States)

David J. Cuccia, Modulated Imaging, Inc. (United States) 
2 Advanced Molecular Imaging Methods

Amaan Mazhar, Modulated Imaging, Inc. (United States)

Pablo A. Valdes, Brigham and Women's Hospital (United States)

3 Clinical Fluorescence Imaging Systems

Martijn Van de Giessen, Leiden University Medical Center

(Netherlands)

Nicholas J. Durr, Beth Israel Deaconess Medical Center

(United States)

4 Molecular Contrast Agents

Jean-Luc Coll, INSERM (France)

Walter J. Akers, Washington University School of Medicine in St. Louis (United States)

5 Preclinical Applications and Clinical Translation

Kenneth M. Tichaver, Illinois Institute of Technology (United States)

Takeaki Ishizawa M.D., The University of Tokyo (Japan)

6 Clinical Applications

Summer L. Gibbs, Oregon Health \& Science University (United States)

Brian C. Wilson, University Health Network (Canada) 


\section{Introduction}

The field of Molecular-Guided Surgery using optical techniques has been growing exponentially over the last decade, and is now recognized as one of the most promising fields that can have an impact on patient care in the near future. As such, the number and the quality of the contributions presented at the conference for its first edition were outstanding. The conference covered a wide range of topics from endogenous to exogenous contrast methods, all the way from the bench to the bedside. Every session included invited presentations from the top research groups in the world that complemented outstanding contributed presentations through the entire conference stream. Importantly, participants from different research horizons were present - mainly scientists, engineers and clinicians - and contributed to enrich the conference content by sharing their perspectives and experiences about Molecular-Guided Surgery.

On the side of emerging technologies, the field is witnessing the rise of new and promising tools using endogenous molecular contrast for guiding surgery, a rising topic in the field due to its fast translational potential and its established sensitive and specific diagnostic capabilities. While it was clear that such an approach is very promising, several groups also highlighted the fact that this topic has to mature and solve significant problems related to integrating the technology into clinical workflow, and providing real-time wide-field images for macroscopic applications. These difficulties, mainly related to technology and methods, however, are balanced with the relative ease for taking imaging systems by themselves into the clinic, in a short term, due to the simplicity of the approval process as compared to methods that make use of contrast agents.

Fluorescence-guided surgery has played a leading role in pulling the field forward, and both the diversity and the originality of the research clearly demonstrate its potential clinical impact. From the device side, more ergonomic tools adapted for clinical scenarios are being designed and translated into practice, with a particular emphasis on endoscopic devices, both in rigid and flexible formats. From the methods aspect, original approaches to increase the sensitivity and the specificity - such as pulsed illumination, attenuation correction or dual tracer imaging - are being developed and demonstrate promise during preclinical implementations.

Finally, on the contrast agent side, the field is seeing two main parallel progresses: on one side, the use of non-specific off-label use of FDA approved contrast agents such as indocyanine green and methylene blue; and on the other, several research groups and industries are developing novel specific contrast agents. The latter is clearly the most awaited and draws significant attention and excitement, especially as these developments take place in the perspective of 
clinical trials and first-in-human studies, a long-standing milestone for the field of fluorescence-guided surgery to achieve.

Altogether, the field of Molecular-Guided Surgery is certainly making a significant impact on the translation of optical methods to solve real clinical problems that need immediate and decisive feedback to surgeons. While both endogenous and exogenous methods exhibit distinct features and differ greatly in nature, it is anticipated that each method should be able to address niche needs in the clinic. This conference-bringing together speakers on the technology, molecules and applications - is an ideal forum in which to carry out these discussions.

Brian W. Pogue Sylvain Gioux 